Patrycja Matusiak

Uniwersytet Śląski w Katowicach

iD ORCID: 0000-0002-4752-5942
OBLICZA WOJNY

TOM 4 • MIASTO I WOJNA

ŁóDŹ 2021 • ISBN 978-83-8220-617-3 • s. 13-26

https://doi.org/10.18778/8220-617-3.02

\title{
„PER SPECIEM VENANDI” LIWIUSZ O „UPOLOWANIU” TARENTU PRZEZ HANNIBALA
}

Streszczenie. Autorzy antyczni - Polibiusz, Liwiusz i Appian - opisali zdobycie Tarentu przez Hannibala w 212 r. p.n.e. w czasie II wojny punickiej. Podstęp związany był z działaniem Filemenosa, który pod pozorem polowania wpuścił do miasta Hannibala i Kartagińczyków, dostarczających mu zwierzyny. Rzymski historyk w większym stopniu niż greccy uczeni zwraca uwagę na efekt ostatniego z polowań, a upolowany wielki dzik staje się metaforą samego miasta oraz prefiguracją Hannibala. Podstęp ten należy widzieć na tle innych sposobów zdobywania miast w czasie wojny, jak i w kontekście podstępów punickich (Punicae artes).

Słowa kluczowe: Hannibal, Tarent, Il wojna punicka, polowanie, dzik

Podczas działań wojennych niezwykle ważne staje się zdobywanie nowych terenów przez wojska atakujące, jak i utrzymanie terytorium przez obronę. Antyczni autorzy zajmujący się problematyką strategematów - Rzymianin Frontyn z I w. n.e. oraz Grek Poliajnos z II w. n.e. poświęcili część swoich dzieł podstępom wojennym, podobnie jak Flawiusz Wenecjusz Renat podrozdziały Zarysu wojskowości. Eneasz Taktyk, autor z IV w. p.n.e., napisał zaś traktat Obrona oblężonego miasta. To oczywiście niejedyne przykłady traktatów wojskowych $^{1}$, zachowanych i przetłumaczonych na język polski. Cennych wiadomości dostarczają także autorzy dzieł historiograficznych - w przypadku

${ }^{1}$ Inne dzieła na ten temat, wchodzące w skład rękopisu spisanego na polecenie cesarza Konstantyna VII i zawierającego właśnie Obronę oblężonego miasta wymienia B. BurligA. Vide: IDEM, Pedagogika przetrwania, czyli antyczne trust no one, [w:] ENEASZ TAKTYK, Obrona oblężonego miasta, przekł. B. BuRLIGA, Warszawa 2007, s. 31-32. 
II wojny punickiej to przede wszystkim Polibiusz, Liwiusz, Appian i pomniejsi historycy. Zagłębiając się w dzieje wojny Hannibala, można zauważyć, że oprócz wielkich bitew będących symbolami tej wojny, na drugi plan wysuwa się dynamiczna akcja zdobywania (i tracenia) ze zmiennym szczęściem miast na terenie Italii.

Sposoby zdobywania miast były różne: od typowych dla sztuki wojennej szturmu i oblężenia (podczas których bardzo często mieszkańcy cierpieli głód, a nierzadko ponosili samobójczą śmierć), przez pertraktacje i polityczne umowy, a nawet groźby, po różnego rodzaju podstępy i wreszcie zdrady. Kombinację tych dwóch ostatnich działań znajdziemy w opisie zdobycia Tarentu przez Hannibala w 212 r. p.n.e. (niektórzy badacze datują to wydarzenie na zimę 213/212 r. p.n.e. najpewniej za samym Liwiuszem)², a także późniejszej wersji Fabiusza z 209 r. p.n.e. Najobszerniej relacjonuje to wydarzenie Polibiusz ${ }^{3}$ w dziele zachowanym fragmentarycznie, z którego być może korzystał Liwiusz. Appian ${ }^{4}$ prezentuje tę historię skrótowo i nieco odmiennie, być może za Frontynem, który umieścił to wydarzenie w swojej kolekcji strategematów i użył tego samego, odmiennego od tradycji polibiańsko-liwiańskiej, imienia osoby zaangażowanej w zdradę $e^{5}$. Dyskusje nad źródłami doprowadziły badaczy do ustalenia genezy dzieł Polibiusza i Liwiusza - dla Greka głównym źródłem miał być towarzyszący Hannibalowi historyk Silenos, dla Rzymianina - Coeliusz Antypater, który miał korzystać właśnie z Silenosa, o czym przekonywał Alfred Klotz ${ }^{6}$. Niewyklu-

${ }^{2}$ Liv. 25, 11, 20. S.J. Northwood, Livy and the Early Annalists, [w:] Studies in Latin Literature and Roman History, t. 10, ed. C. Deroux, Bruxelles 2000, s. 50; D. Hoyos, Mastering the West. Rome and Carthage at War, Oxford 2015, s. 147; D. Moore, Polybius: Experience and the Lessons of History, Leiden-Boston 2020, s. 58.

3 Polyb. 8, 26-36 (Cod. Urb. Fol. 114v).

${ }^{4}$ App. Annib. 32 (133) - 34 (147). Na temat źródeł Appiana vide: I. Hahn, Appian und seine Quellen, [w:] Romanitas - Christianitas. Untersuchungen zur Geschichte und Literatur des römischen Kaiserzeit. Johannes Straub zum 70. Geburstag am 18. Oktober 1982 gewidmet, hrsg. G. WIRTH, Berlin-New York 1982, s. 251-276; N. Biffi, Introduzione, [w:] Appiano di Alessandria, La guerra contro Annibale, introduzione, testo, traduzione e commento a cura di N. BIFFI, Bari 2015, s. 25-26; Ch.G.LeIdL, Appians 'Annibaike': Aufbau-Darstellungstendenzen-Quellen, [w:] Aufstiegund Niedergang der römischen Welt, teil 2, Bd 34, hrsg. W. HaAsE, Berlin-New York 1993, s. 446-459.

${ }^{5}$ Front. 3, 36.

${ }^{6}$ A. Klotz, Livius und seine Vorgänger, Heft 1, Amsterdam 1964, 118-119, 165. Na temat dyskusji o źródłach tego miejsca vide: F.W. Walbank, A Historical Commentary on Polybius, vol. 2, (Commentary on Books VII-XVIII), Oxford 1967, s. 100-101, J. von Ungern-STERnBerg, Livy and the Annalistic Tradition, [w:] A Companion to Livy, ed. B. Mineo, Chichester 2015, s. 172; 
czone, że Liwiusz posiłkował się także tekstem samego Polibiusza (w trzeciej dekadzie nie zawsze jednak trzymając się go ściśle ${ }^{7}$ ). W związku z tym Michael von Albrecht proponuje przyjęcie dwóch tradycji: Coeliusz i Polibiusz versus Waleriusz Antias i Claudius Quadrigarius ${ }^{8}$. Frank Walbank zwraca uwagę, że narracja Polibiusza (a zatem i Liwiusza) dzięki tym źródłom została napisana z kartagińskiego punktu widzenia9.

Liwiusz, zanim zgodnie z chronologią zaczął opisać zdobywanie Tarentu, zapowiada akcję (jak to często ma w zwyczaju): „cum Tarentinorum defectio iam diu et in spe Hannibali et in suspicione Romanis esset” ${ }^{10}$. Być może dlatego, że już w 214 r. p.n.e. pojawili się u przebywającego nad Jeziorem Awerneńskim Hannibala wysłańcy z Tarentu z ofertą przymierza i oddania miasta ${ }^{11}$. Liwiusz każe Hannibalowi się rozmarzyć: „ipsum ingens cupido incesserat Tarenti potiundi"12, ponieważ zdobycie miasta wprowadziłoby wojnę w nową fazę, a bliski 212 r. był według historyków punktem równowagi między obiema potęgami ${ }^{13}$. Miasto to odegrało pewną rolę w wybuchu I wojny punickiej ${ }^{14}$, a oprócz bogactwa miało ogromny potencjał - port, do którego mogły przypłynąć posiłki, m.in. od Filipa V:

J. Richardson, The Complication of Quellenforsching: The Case of Livy and Fabius Pictor, [w:] A Companion to Livy..., s. 178 sqq. oraz J.-A. FoucAult, Tite-Live traducteur de Polybe, REL 1968, t. 46, s. 208-221.

7 J.D. Chaplin, Livy's Exemplary History, Oxford 2001, s. 25.

8 M. von Albrecht, A History of Roman Literature. From Livius Andronicus to Boethius, vol. 1, Leiden-New York-Köln 1997, s. 835.

9 F.W. WAlbank, op. cit., s. 101; T.J. Moore, Livy's Hannibal and the Roman Tradition, [w:] Livy and Intertextuality, ed. W. Polleichtner, Trier 2010, s. 140.

${ }^{10}$ Liv. 25, 7, 10: „Oderwania się Tarentu od Rzymu i Hannibal dawno się spodziewał, i Rzymianie podejrzewali tę możliwość” (wszystkie przekłady Liwiusza - Mieczysław Brożek).

${ }^{11}$ Liv. 24, 13, 1-5. O trudnej sytuacji miast południowoitalskich: E. Macdonald, Hannibal. A Hellenistic Life, New Haven-London 2015, s. 162; o innej perspektywie zdobycia Tarentu jako „wyzwolenia” i altera historia Liwiusza: J.T. CHLup, Maior et clarior victoria: Hannibal and Tarentum in Livy, „The Classical World” 2009, vol. 103, s. 31; A. ERskine, Hannibal and the Freedom of the Italians, „Hermes” 1993, B. 121, s. 60-62.

${ }^{12}$ Liv. 24, 13, 5: „a jego samego ogarnęło ogromne pragnienie zdobycia tego miasta”.

13 Polibiusz datuje ten punkt jednak na 210 r. p.n.e. R.T. Ridley, Livy and the Hannibalic War, [w:] The Roman Middle Republic. Politics, Religion, and Historiography c. 400-133 B.C., ed. Ch. Bruun, Rome 2000, s. 14; J.T. Chlup, Maior et clarior victoria: Hannibal and Tarentum in Livy..., s. 21.

${ }^{14}$ Liv. Per. 14; Polyb. 3, 26 o traktatach kartagińsko-rzymskich oraz D. Hoyos, The Outbreak of War, [w:] A Companion to the Punic Wars, ed. D. Hoyos, Chichester 2011, s. 131-148. 
urbem esse videbat cum opulentam nobilemque tum maritimam et in Macedoniam opportune versam, regemque Philippum hunc portum, si transiret in Italiam, Brundisium cum Romani haberent, petiturum ${ }^{15}$.

Kiedy Hannibal w końcu dotarł pod Tarent z nadzieją na oddanie mu miasta $^{16}$, chcąc pozyskać sobie mieszkańców, powściągnął działania swojego wojska, które do tej pory siało zniszczenie wszędzie tam, gdzie przechodziło ${ }^{17}$. Niestety nie zjawił się żaden z posłańców, którzy odwiedzili Hannibala wcześniej, więc wódz ruszył stamtąd do Salapii, stosując jeden ze swoich chwytów w celu pozyskania sprzymierzeńców: „simulata lenitas”, czyli udawaną łagodność, znajdującą się także w arsenale Rzymian ${ }^{18}$ :

vana promissa se temere secutum cernens castra inde movit, tum quoque intacto agro Tarentino, quamquam simulata lenitas nihildum profuerat, tamen spe labefactandae fidei haud absisten ${ }^{19}$.

Dwukrotnie Liwiusz podkreśla nadzieję Hannibala, że miasto zostanie zdradzone: „ad certiorem spem proditionis” ${ }^{20}$ oraz „spe per proditionem urbis Tarentinorum potiundae"21. Historyk bardzo celnie nazywa sposób zdobycia miasta, bo 'proditio' to nic innego niż 'zdrada'. Podobnie definiuje ten sposób Frontyn, który umieścił historię o podbiciu Tarentu w rozdziale De eliciendis ad proditionem - „O nakłanianiu do zdrady” ${ }^{2}$, oraz Plutarch, opisując w biografii Fabiusza Maksymusa odzyskanie miasta zdobytego poprzez zdradę (,દ̌k $\left.\pi p o \delta 0 \sigma i \alpha s^{\prime \prime}\right)^{23}$.

${ }^{15}$ Liv. 24, 13, 5: „Widział, że jest zasobne i sławne, a przede wszystkim nadmorskie, bardzo dogodnie położone od strony Macedonii, i że król macedoński Filip, przeprawiając się do Italii, przypłynąć może do tego właśnie portu, skoro Brundyzjum trzymają Rzymianie”. Port jednak był strzeżony przez Rzymian: Liv. 23, 32, 18; 23, 33, 4; 23, 38, 9.

${ }^{16}$ Liv. 24, 17, 8: „Tarentum ad certiorem spem proditionis proficiscitur”.

17 Liv. 24, 20, 9: „cum maxima omnium quacunque ierat clade”; Liv. 24, 20, 10: „ad conciliandos animos Tarentinorum".

${ }^{18}$ Liv. 26, 16, 12: „lenitatis species” (Kapua); 39, 55, 1.

19 Liv. 24, 20, 15: „Widząc więc, że poszedł pochopnie za próżnymi obietnicami, odmaszerował stamtąd, nie tykając i tym razem pól tarentyńskich. Bo choć udana łagodność na razie nic nie pomogła, nie tracił przecież nadziei, że uda mu się złamać wierność dla Rzymu”.

${ }^{20}$ Liv. 24, 17, 8.

${ }^{21}$ Liv. 25, $1,1$.

${ }^{22}$ Front. 3, 3, 6 .

${ }^{23}$ Plut. Fab. 21, 1. 
Przyczynę, która w 212 r. p.n.e. ostatecznie doprowadziła do tej zdrady i oddania miasta, stanowiła śmierć Fileasa z Tarentu, posła, który po przekupieniu strażników uwolnił zakładników z Tarentu i Turiów. Uciekinierów obito rózgami i strącono ze skały („caesi de saxo deiciuntur”24. Emocją, która doprowadziła do zdrady, była ta najbardziej epicka: gniew („animos inritavit”) ${ }^{25}$ z powodu ciężkiej kary („atrocitas poenae” ${ }^{26}$ oraz haniebnego sposobu śmierci („foede interemptos”) ${ }^{27}$. 'Foede’ tłumaczyć możemy jako 'strasznie', 'wstrętnie’, 'przerażająco', ale także właśnie 'haniebnie', 'sromotnie', 'skandalicznie', 'niegodziwie’. Łączy się to z polisemicznym rzeczownikiem 'atrocitas', który oznacza 'potworność, 'grozę', ale też 'dzikość, 'barbarzyństwo', 'srogość' czy 'surowość, którą zwykło się łączyć z 'poena' w wyrażeniu 'surowość kary' - kara ta więc z powodu swojej surowości miała wywoływać grozę. Strącenie ze Skały Tarpejskiej jest tylko kilka razy wymienione przez Liwiusza jako sposób wymierzania śmierci. Ponieśli ją: strażnik, który nie zauważył wtargnięcia Gallów na Kapitol w 390 r. p.n.e. ${ }^{28}$; Marek Manliusz, dzielny obrońca Kapitolu, a następnie sprawca „zamieszek manliańskich”29, skazany za zdradę państwa w $384 \mathrm{r}$. p.n.e. ${ }^{30} ; 370$ zbiegów pojmanych przez Rzymian w miastach zdobytych w $214 \mathrm{r}$. p.n.e. - tych również najpierw obiczowano ${ }^{31}$; Q. Metellus, cenzor ${ }^{32}$; niewolnik, za którego sprawą zabito Publiusza Sulpicjusza ${ }^{33}$; senator S. Licinius ${ }^{34}$.

Do Hannibala z propozycją oddania miasta przybyli Nikon i Filemenos, stojący na czele grupki trzynastu młodzieńców wywodzących sięz arystokracji. Wyszli z miasta pod pozorem polowania i aby uprawdopodobnić ten powód, wzięli ze sobą bydło Kartagińczyków. Owo polowanie, określone jako „per speciem venandi” („pod pozorem wyprawy na polowanie”) ${ }^{35}$, nie do końca jest tożsame

24 Liv. 25, 7, 14.

25 Liv. $25,8,1$.

26 Liv. 25, 8, 1.

27 Liv. 25, 8, 2.

28 Liv. 5, 47, 11.

29 Liv. 6, 18, 1: Manliana seditione.

30 Liv. 6, 20, 11: „tribuni de saxo Tarpeio deiecerunt; locusque idem in uno homine et eximiae gloriae monumentum et poenae ultimae fuit"; Liv. Per. 6.

31 Liv. 24, 20, 6.

32 Liv. Per. 59.

33 Liv. Per. 77.

34 Liv. Per. 80.

35 Liv. 25, 8, 4. 
z „praedandi causa” („na szukanie zdobyczy”)36 i późniejszą „praeda”37. 'Venari' oznacza 'iść na polowanie', 'polować', a więc czynność kojarzoną ze szlachetną tradycją. 'Praedari' oznacza zaś co prawda 'zdobywać pokarm przez polowanie', ale w pierwotnym znaczeniu 'zdobywać łup (rabunkiem/na wojnie)', 'rabować', 'grabić', odnosiłoby się to więc do wojennych sposobów aprowizacji i pasowało bardzo dobrze do „upolowania” bydła kartagińskiego.

Liwiusz i Polibiusz nazywają głównego bohatera Filemenosem, u Appiana i Frontyna, którzy być może korzystali z innej tradycji, nosi on imię Kononeus, choć badacze nie wykluczają, że mogło to być drugie imię Filemenosa, podobnie jak u Nikona, zwanego też Perconem ${ }^{38}$.

Kluczowy fragment opisu analizowanego podstępu brzmi tak:

haec ubi convenerunt, tunc vero Philemenus consuetudinem nocte egrediundi redeundique in urbem frequentiorem facere. et erat venandi studio insignis, canesque et alius apparatus sequebatur; captumque ferme aliquid aut ab hoste ex praeparato adlatum reportans donabat aut praefecto aut custodibus portarum. nocte maxime commeare propter metum hostium credebant. ubi iam eo consuetudinis adducta res est, ut, quocumque noctis tempore sibilo dedisset signum, porta aperiretur, tempus agendae rei Hannibali visum est ${ }^{39}$.

Istota podstępu była bardzo prosta: Filemenos miał wychodzić nocą na polowanie i w ten sposób przyzwyczajać wszystkich do tego obyczaju, by ułatwić wejście Kartagińczykom do miasta, ponieważ po jakimś czasie otwierano mu bramę jedynie na jego ciche gwizdnięcie („sibilo dedisset signum”). W tym czasie Hannibal znajdował się trzy dni drogi od Tarentu i dla niepoznaki udawał

36 Liv. 25, 8, 6 .

37 Liv. 25, 8, 7.

38 F.W. Walbank, op. cit., s. 102. Liv. 26, 39, 15: „in Romana nave ipse Quinctius erat, in Tarentina Nico, cui Perconi fuit cognomen, non publico modo sed privato etiam odio invisus atque infestus Romanis, quod eius factionis erat, quae Tarentum Hannibali prodiderat".

39 Liv. 25, 8, 9-11: „Po tym porozumieniu dopiero to Filemenos coraz częściej uprawiał swój zwyczaj wychodzenia z miasta i wracania do niego nocą. A znany był jako zapalony myśliwy i chodził z psami i innym myśliwskim sprzętem. Gdy złowił coś przypadkiem albo przypędził z przygotowanej przez wroga zdobyczy, częstował tym dowódcę załogi, to znów strażników bramy. A ci byli przekonani, że on dlatego wychodzi na te łowy właśnie nocą, ponieważ boi się nieprzyjaciela. Wreszcie do tego stopnia przyzwyczajono się do tego, że w każdej chwili, gdy tylko dał znak gwizdnięciem, brama się otwierała. Wtedy Hannibal uznał, że czas zabrać się do dzieła”. 
chorego („aegrum simulabat”) ${ }^{40}$. Filemenos był zapalonym myśliwym („venandi studio insignis”), więc nikogo nie dziwiło, że wychodzi regularnie na polowania ('commeare' oznacza właśnie 'częste chodzenie tam i z pow rotem') ${ }^{41}$, nawet nocą - porę przypisywano lękowi przed nieprzyjacielem ('propter metum hostium credebant'). Na dodatek miał taki zwyczaj już wcześniej, bo Liwiusz używa słów „consuetudinem frequentiorem facere”. Ciekawe jest sformułowanie „captumque ferme aliquid aut ab hoste ex praeparato adlatum reportans”, świadczące o efektywności Filemenosa - miał łapać coś „ferme”, co Mieczysław Brożek oddaje jako „przypadkiem”, lub przyprowadzać coś z zasobów Kartagińczyków, którzy wcześniej obiecali, że będzie mógł bezpiecznie i bez walki korzystać z ich pastwisk („tuto ac sine certamine id facturos promissum est”) ${ }^{42}$.

Filemenos miał polować z psami i z użyciem sprzętu myśliwskiego („canesque et alius apparatus sequebatur” ${ }^{43}$, historyk nie informuje jednak, czy też w taki sposób udawał polowanie. Wydaje się, że to ogólna charakterystyka jego sposobu polowania. Natomiast w nocy, kiedy zostało zdradzone miasto, wrócił z łowów z dwoma mężczyznami dźwigającymi dzika oraz z towarzyszącym mu myśliwym „cum expedito venatore”ł4 (u Polibiusza: z czterema mężczyznami dźwigającymi odyńca na noszach). Po zabiciu strażnika - u Liwiusza myśliwskim oszczepem („,venabulo”) ${ }^{45}$, u Polibiusza został on zatłuczony - przez bramę przeszło około trzydziestu uzbrojonych ludzi, u Polibiusza wyprzedzających prawie tysiąc zgromadzonych pod bramą żołnierzy, a u Liwiusza regularną kolumnę wojska. Appian utrzymuje, że myśliwy wrócił do miasta z uzbrojonymi ludźmi Hannibala, („pod szatami w pancerze i miecze, na zewnątrz jednak przebranych jako myśliwi”46). Podobnie pisze Frontyn („quadam nocte Hannibal venatorum

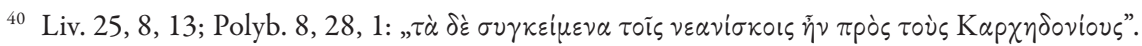
Jeśli przyjąć datowanie zdobycia Tarentu na zimę 213/212 r. p.n.e., Hannibal miałby tam obóz zimowy. J.F. LAzenby, Wojna Hannibala. Historia militarna drugiej wojny punickiej, przekł. T. ŁADOŃ, Oświęcim 2015, s. 163.

41 Liv. 25, 8, 10; 25, 9, 13.

42 Liv. 25, 8, 6.

43 O ekwipunku potrzebnym do upolowania dzika i samym polowaniu: A.J. Butler, Sport in Classic Times, London 1975, s. 81-88; vide: J.K. Anderson, Hunting in the Ancient World, Berkeley-Los Angeles-London 1985, s. 83-100; D.B. Hull, Hounds and Hunting in Ancient Greece, Chicago and London 1964.

44 Liv. 25, 9, 14.

45 Liv. 25, 8, 14.

46 App. Annib. 32 (134) [przekł. L. Piotrowicz]. 
habitu Poenos comitibus eius immiscuit" ${ }^{47}$. Z najbardziej rozbudowanej wersji Polibiusza dowiadujemy się, że spisek zaplanowany był na dzień biesiady (pijatyki) w Muzejonie, w której udział miał wziąć naczelnik miasta Gajusz Liwiusz. Historyk rzymski nie podaje jednak nazwiska naczelnika, by - jak zauważa Serge Lancel - nie sprawiać przykrości „gens” Livia ${ }^{48}$. U Polibiusza również rozbudowana jest sekwencja dawania znaków Hannibalowi, który miał do miasta wejść przez Bramę Temenicką (u Liwiusza: „Temenitida” - Tymenitydzką) ${ }^{49}$. Rzymski historyk odnotowuje jedynie, że błyśnięto i odbłyśnięto ogniem, oraz że w tej części miasta znajdują się groby. Polibiusz natomiast precyzuje nawet, na czyim grobie miał pojawić się sygnał świetlny: „Hannibal miał (...) zapalić ogień na grobie, który jedni nazywają grobem Hyakinta, drudzy - Apollona” ${ }^{50}$. Nikon i inny ze zdrajców, Tragiskos, mieli odpowiedzieć ogniem z grobowca Pytionikosa. Szczegółowość relacji Polibiusza i zgodność co do szczegółów u Liwiusza każe przyjąć tezęo wspólnym prokartagińskim źródle.

W narracji Liwiusza, inaczej niż u autorów greckich, pojawia się opis ostatniej zdobyczy Filemenosa. Dzik, którego przydźwigało dwóch ludzi (u Polibiusza - czterech), był niejako „dzikiem trojańskim” - odwracając uwagę strażnika, umożliwił wrogowi wejście do miasta. Liwiusz nazywa go w tym epizodzie 'bestia's1, czyli ‘dzikie zwierzę' oraz 'aper' właśnie, czyli 'dzik’52. Polibiusz używa

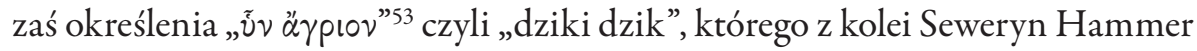
określa w swoim tłumaczeniu jako „odyńca”. Epitety, którymi rzymski historyk opisuje dzika, każą dopatrywać się hiperbolizującej metafory - owa wielkość upolowanego zwierza świadczyć może, że nie o upolowanie dzika tu chodziło. Upolowane zostało miasto, na dodatek nie przez Filemenosa, a przez ofiarodawcę dzika (tego i poprzednich), którego tak ofiarnie dźwigali - Polibiusz precyzuje, że Hannibal „w wiadomym celu przygotował był odyńca” ${ }^{4}$. W jego wersji Filemenos również woła strażnika, ponaglając go do otworzenia bramy,

47 Front. 3, 3, 6.

48 S. LANCEL, Hannibal, Warszawa 2001, s. 201.

49 Polyb. 8, 27; Liv. 25, 9, 9.

50 Polyb. 8, 30 [przekł. S. HAMmer].

51 Liv. 25, 9, 13.

52 Liv. 25, 9, 14.

53 Polyb. 8, 26, 10; 8, 29, 4; 8, 29, 6.

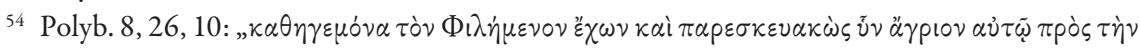

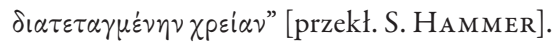


bo ciężko im dźwigać dzika ${ }^{55}$, jednak Liwiusz dobitniej podkreśla jego ciężar („grandis bestiae onus" ${ }^{56}$ ), każąc nieostrożnemu strażnikowi podziwiać jego wielkość: „incautius miraculo magnitudinis”57. Chwilę wcześniej czytamy, że Filemenos był przewodnikiem Hannibala „cum solito captae venationis onere”58, czyli dosłownie „ze zwykłym ciężarem zwierzyny”. 'Venatio’ oprócz ‘polowania' oznacza także ‘zwierzynę', ‘zdobycz myśliwską i ‘dziczyznę”. Mieczysław Brożek zaproponował przekład: „ze zwykłą ilością ułowionej zwierzyny”, ale wydaje mi się, że w kontekście zastosowanego później terminu 'onus'59 użycie kategorii wagi, nie ilości, będzie właściwsze. Jeśli więc zdobycz, którą niósł ze sobą Filemenos, miała być przeciętna, przeczy to użyciu słowa 'miraculum', czyli czegoś, co budzi podziw lub zdumienie ${ }^{60}$. Druga możliwość interpretacji tego polowania prowadzi w stronę samego Hannibala - metaforycznie młodzieńcy przydźwigali tej nocy do Tarentu Hannibala, ów potężny odyniec - „dzik tarentyjski” przypominający funkcją konia trojańskiego, mógł być moim zdaniem prefiguracją Kartagińczyka.

Miasto - oprócz zamku - zostało zdobyte i nastąpił kolejny etap - „direptio"61. Zastosowany podstęp, wpisujący się w katalog „punickich sztuczek” („Punicae artes”), choć tym razem nazwany tak tylko raz (ale dopiero w toku późniejszej narracji), miał jednak kontynuację. Historia zatoczyła koło - w 209 r. p.n.e. Tarent został odbity przez Fabiusza Maksymusa. Fortel - polegający na przekonaniu dowódcy załogi bruttyjskiej, zakochanego w siostrze rzymskiego żołnierza, do zdradzenia miasta - został wymieniony w zbiorze podstępów wojennych, sporządzonym przez Poliajnosa, greckiego autora z II w. n.e., dla którego źródłem mogli być Liwiusz i Plutarch ${ }^{62}$. Poliajnos konkluduje: „Za ten podstęp podziwiano go [Fabiusza Maksymusa] szczególnie, pokonał

55 Liv. 25, 9, 13: „dicenti vix sustinerei grandis bestiae onus”.

56 Liv. 25, 9, 13.

57 Liv. 25, 9, 14.

58 Liv. $25,9,8$.

59 Liv. 25, 9, 13.

${ }^{60}$ Liv. 25, 9, 14.

${ }^{61} \mathrm{Na}$ temat „direptio” vide wyczerpujące studium: A. ZIó£Kowski, Urbs direpta. Los miasta zdobytego przez Rzymian w okresie wielkich podbojów, [w:] Świat antyczny. Stosunki spoteczne, ideologia ipolityka, religia. Studia ofiarowane Izie Bieżunskiej-Matowist w pięćdziesięciolecie pracy naukowejprzezJej uczniów, Warszawa 1988, s. 87-116; IDEM, Urbs direpta, or How the Romans Sacked Cities, [w:] War and Society in the Roman World, eds J. Rich, G. Shipley, London-New York 1993, s. 69-91.

${ }^{6}$ Plut. Fab. 21. 
bowiem Hannibala, który większość swoich zwycięstw odniósł właśnie dzięki podstępom i fortelom"63. Liwiusz na wieść o zdobyciu przez Rzymian Tarentu każe Kartagińczykowi powiedzieć: „«et Romani suum Hannibalem» inquit «habent: eadem qua ceperamus arte Tarentum amisimus»"64, co w przekładzie Mieczysława Brożka brzmi: „Mają więc i Rzymianie swego Hannibala. Jakim sposobem zdobyliśmy Tarent, takim też utraciliśmy to miasto”. Następuje tu więc pewna hannibalizacja rzymskiego wodza, stworzenie rzymskiego Hannibala, który odnosi sukces dzięki zastosowaniu kartagińskich metod ${ }^{65}$. Taki „drugi Hannibal” - zależnie od okoliczności - może być pozytywnym lub negatywnym egzemplum ${ }^{66}$. „Eadem arte” z wypowiedzi Kartagińczyka można przełożyć jako „taką samą sztuczką" lub „tym samym podstępem”"67. W opisie rzymskiego fortelu, także opierającego się przecież na zdradzie, ani razu nie pada u Liwiusza słowo 'proditio', choć wspomniany został Filemenos jako sprawca wcześniejszej zdrady: „qui proditionis ad Hannibalem auctor fuerat" ${ }^{\text {"68 }}$.Jak wykazała Anna Zawadzka, jest to pewien autostereotyp w rzymskiej literaturze historiograficznej ${ }^{69}$.

Zastosowany przez Hannibala fortel, polegający na imitacji polowania w celu uzyskania dostępu do portowego miasta, stanowił prawdziwe polowanie, którego rezultatem był Tarent jako trofeum. Wersja Liwiusza, zwracając szczególną uwagę na elementy polowania, pozwala na metaforyzację tej zdobyczy. To Hannibal, a nie Filemenos, jawi się tu jako wytrawny myśliwy, a więc jest to zgodne z obrazem Kartagińczyka jako dobrego stratega. Ten drobny epizod w dziejach

${ }^{63}$ Polyaen. 8, 14, 3 [przekł. M. BorowskA].

${ }^{64}$ Liv, 27, 16, 10; Plut. Fab. 23, 1.

65 P. Matusiak, Obraz Hannibala wliteraturze antycznej, Katowice 2015, s. 127-128; D.S. Levene, Livy on the Hannibalic War, Oxford 2012, s. 230-231; A. Menl, Roman Historiography. An Introduction to its Basic Aspects and Development, trans. H.-F. Mueller, Chichester 2011, s. 109.

${ }^{66}$ C. STоскs, The Roman Hannibal. Remembering the Enemy in Silius Italicus' Punica, Liverpool 2014, s. 9. Na temat alter Hannibal vide: P. MATUsia o, op. cit., s. 113-152.

${ }^{67}$ E.L. Wheeler, Stratagem and the Vocabulary of Military Trickery, Leiden-New YorkKøbenhavn-Köln 1988, s. 52, passim.

${ }^{68}$ Liv. 27, 16, 3.

${ }^{69}$ A. ZAWADZKA, Romanis artibus vincere: virtute, opere, armis - o pewnym autostereotypie u Rzymian, [w:] Timai. Studia poświęcone profesorowi Wtodzimierzowi Lengauerowi przez uczniów i mtodszych kolegów z okazji Jego 60. urodzin, red. A. Wolicki, Warszawa 2009, s. 233-256. Vide: także nt. podstępów w Bellum Civile Appiana: E. Cowan, Deceit in Appian, [w:] Appian's Roman History. Empire and Civil War, ed. K. WELCH, Swansea 2015, s. 183-203. 
całej wojny wpisuje się w szerszą kategorię stosowanych w czasie II wojny punickiej podstępów polegających na udawaniu („simulare” i „dissimulare”). Pozwala też dorzucić cegiełkę zarówno do głębszego poznania literackiego wizerunku Kartagińczyka, jak i do lepszego rozumienia mechanizmów strategii językowych rzymskiego historyka, który przekazał nam własną, nieco odmienną wersję opowieści o dziku tarentyjskim.

\section{BIBLIOGRAFIA}

\section{Źródła drukowane}

Appian z Aleksandrii, Historia rzymska, t. 1, przekł., oprac. i wstępem opatrzył L. Piotrowicz, Wrocław-Warszawa 2004.

Eneasz Taktyk, Obrona oblężonego miasta, przekł., wstępem, przypisami i komentarzem opatrzył B. Burliga, Warszawa 2007.

Frontinus, Stratagems. Aqueducts of Rome, with an English Translation by C.E. Bennett, M.B. McElwain, Cambridge, MA 1925.

Frontyn, Podstępy wojenne, przekł., wstępem i przypisami opatrzył B. Burliga, Wrocław 2016.

Plutarch, Lives, with an English Translation by B. Perrin, vol. 3, Cambridge, MA-London 1916.

Poliajnos, Podstępy wojenne, przekł., wstępem i przypisami opatrzyła M. Borowska, Warszawa 2003.

Polibiusz, Dzieje, t. 1, przekł., opracował i wstępem opatrzył S. Hammer, Wrocław-Warszawa 2005.

Polybius, Historiae, vol. 1, ed. T. Büttner-Wobst, Leipzig 1893.

Titus Livius, Ab urbe condita, ed. G. Weissenborn, M. Mueller, Pars I: Libri I-X, Leipzig 1898; Pars II: Libri XXI-XXX, Leipzig 1884.

Tytus Liwiusz, Dzieje Rzymu od zatożenia miasta. Ksieggi XXI-XXVII, przekł. i oprac. M. Brożek, komentarz M. Brożek, J. Wolski, Wrocław-Warszawa-Gdańsk 1974.

Walbank F.W., A Historical Commentary on Polybius, vol. 2 (Commentary on Books VIIXVIII), Oxford 1967. 


\section{Opracowania}

Albrecht M. von, A History of Roman Literature. From Livius Andronicus to Boethius, vol. 1, Leiden-New York-Köln 1997.

Anderson J.K., Hunting in the Ancient World, Berkeley-Los Angeles-London 1985.

Biffi N., Introduzione, [w:] Appiano di Alessandria, La guerra contro Annibale, introduzione, testo, traduzione e commento a cura di N. Biffi, Bari 2015, s. 7-29.

Burliga B., Pedagogika przetrwania, czyli antyczne trust no one, [w:] Eneasz Taktyk, Obrona oblężonego miasta, przekł. B. Burliga, Warszawa 2007, s. 31-45.

Butler A.J., Sport in Classic Times, London 1975.

Chaplin J.D., Livy's Exemplary History, Oxford 2001.

Chlup J.T., Maior et clarior victoria: Hannibal and Tarentum in Livy, „The Classical World” 2009, vol. 103, s. 17-38.

Cowan E., Deceit in Appian, [w:] Appian's Roman History. Empire and Civil War, ed. K. Welch, Swansea 2015, s. 183-203.

Erskine A., Hannibal and the Freedom of the Italians, „Hermes” 1993, B. 121, s. 58-62.

Foucault J.-A., Tite-Live traducteur de Polybe, „Revue des Études Latines” 1968, t. 46, s. 208-221.

Hahn I., Appian und seine Quellen, [w:] Romanitas - Christianitas. Untersuchungen zur Geschichte und Literatur des römischen Kaiserzeit. Johannes Straub zum 70. Geburstag am 18. Oktober 1982 gewidmet, hrsg. G. Wirth, Berlin-New York 1982, s. 251-276.

Hoyos D., Mastering the West. Rome and Carthage at War, Oxford 2015.

Hoyos D., The Outbreak of War, [w:] A Companion to the Punic Wars, ed. D. Hoyos, Chichester 2011, s. 131-148.

Hull D.B., Hounds and Hunting in Ancient Greece, Chicago and London 1964.

Klotz A., Livius und seine Vorgänger, Heft 1, Amsterdam 1964.

Lancel S., Hannibal, Warszawa 2001.

Lazenby J.F., Wojna Hannibala. Historia militarna drugiej wojny punickiej, Oświęcim 2015.

Leidl Ch.G., Appians Annibaike’: Aufbau - Darstellungstendenzen - Quellen, [w:] Aufstieg und Niedergang der römischen Welt, Teil 2, Bd 34, hrsg. W. Haase, Berlin-New York 1993, s. 428-462.

Macdonald E., Hannibal. A Hellenistic Life, New Haven-London 2015.

Matusiak P., Obraz Hannibala w literaturze antycznej, Katowice 2015.

Mehl A., Roman Historiography. An Introduction to its Basic Aspects and Development, trans. H.-F. Mueller, Chichester 2011.

Moore D., Polybius: Experience and the Lessons of History, Leiden-Boston 2020. 
Moore T.J., Livy's Hannibal and the Roman Tradition, [w:] Livy and Intertextuality, ed. W. Polleichtner, Trier 2010, s. 135-167.

Northwood S.J., Livy and the Early Annalists, [w:] Studies in Latin Literature and Roman History, t. 10, ed. C. Deroux, Bruxelles 2000, s. 45-55.

Richardson J., The Complication of Quellenforsching: The Case of Livy and Fabius Pictor, [w:] A Companion to Livy, ed. B. Mineo, Chichester 2015, s. 178-189.

Ridley R.T., Livy and the Hannibalic War, [w:] The Roman Middle Republic. Politics, Religion, and Historiography c. 400-133 B.C., ed. Ch. Bruun, Rome 2000, s. 13-40.

Stocks C., The Roman Hannibal. Remembering the Enemy in Silius Italicus' Punica, Liverpool 2014.

Ungern-Sternberg J. von, Livy and the Annalistic Tradition, [w:] A Companion to Livy, ed. B. Mineo, Chichester 2015, s. 167-177.

Wheeler E.L., Stratagem and the Vocabulary of Military Trickery, Leiden-New YorkKøbenhavn-Köln 1988.

Zawadzka A., Romanis artibus vincere: virtute, opere, armis - o pewnym autostereotypie u Rzymian, [w:] Timai. Studia poświęcone profesorowi Wtodzimierzowi Lengauerowi przez uczniów i mtodszych kolegów z okazji Jego 60. urodzin, red. A. Wolicki, Warszawa 2009, s. 233-256.

Ziółkowski A., Urbs direpta. Los miasta zdobytego przez Rzymian w okresie wielkich podbojów, [w:] Świat antyczny. Stosunki spoteczne, ideologia i polityka, religia. Studia ofiarowane Izie Bieżunskiej-Matowist w pięćdziesięciolecie pracy naukowej przez Jej uczniów, Warszawa 1988, s. 87-116.

Ziółkowski A., Urbs direpta, or How the Romans Sacked Cities, [w:] War and Society in the Roman World, eds J. Rich, G. Shipley, London-New York 1993, s. 69-91.

\section{Patrycja Matusiak}

\section{"PER SPECIEM VENANDI". LIVY ON TARENTUM HAVING BEEN "HUNTED" BY HANNIBAL}

Summary. Ancient authors Polybios, Livy and Appianus described the conquest of Tarentum by trickery by Hannibal in 212 BCE during the Second Punic War. The trick was related to Philemenos, who, under the guise of hunting, let Hannibal and the Carthaginians, who supplied him with game, into the city. The Roman historian, more than the Greeks, draws attention to the effect of the last of the hunts, making the hunted great boar (Tarentum boar) a metaphor for the city itself and a prefiguration of Hannibal. This ruse fits both the ways of conquering cities during the war and the wide variety of Punic deceits.

Keywords: Hannibal, Tarentum, Second Punic War, hunting, boar 